\title{
HERMENÊUTICA JURÍDICA E USO DEFICIENTE DE MÉTODOS NO CONTEXTO DA APLICAÇÃO DO DIREITO NO BRASIL
}

\begin{abstract}
Andreas J. Krell
Doctor Juris pela Freie Universität Berlin. Professor de Direito Ambiental e Constitucional da Faculdade de Direito da Universidade Federal de Alagoas (FDA/UFAL, Maceió, AL), nos cursos de Graduação e de Mestrado. Professor Permanente do PPGD da Faculdade de Direito do Recife (UFPE, Recife, PE). Pesquisador Bolsista do CNPq (PQ - nível 1B). E-mail: <akrell@uol.com.br>.
\end{abstract}

\section{Raíi Moraes Sampaio de Paiva}

Bacharel em Direito pela Faculdade de Direito de Alagoas (UFAL, Maceió, AL). E-mail: $<$ raiisampaio@hotmail.com>.

\begin{abstract}
Resumo: 0 artigo procura analisar a coerência das críticas aos cânones da interpretação no direito brasileiro contemporâneo. Enquanto a doutrina nacional não Ihes dá mais espaço, a prática judicial muitas vezes os emprega sem os devidos cuidados, sobretudo como recurso de autoridade. Nesse contexto, a extinção das formas de método jurídico pode levar ao fechamento do processo de interpretação normativa e diminuir a legitimidade das decisões judiciais, que sofrem com o baixo nível de justificação argumentativa. Orientados por um discurso jurídico-racional que tem por base pretensões de correção, comunicabilidade e representação, os cânones interpretativos ainda têm funções estruturantes e expositivas indispensáveis para a racionalidade da interpretação e aplicação das normas jurídicas.
\end{abstract}

Palavras-chave: Cânones de interpretação. Hermenêutica. Teoria discursiva do direito.

Sumário: 1 Introdução - 2 A hermenêutica jurídica na doutrina brasileira tradicional: despreocupação com a metódica interpretativa - 3 As críticas mais comuns contra os cânones interpretativos 4 Os cânones interpretativos e a racionalidade discursiva - 5 Os elementos literal e sistemático 6 Os elementos teleológico e histórico - 7 Por uma metódica jurídica constitucionalmente correta 80 modelo brasileiro de racionalidade judicial e a argumentação por autoridade - 90 problema da ponderação prévia - $\mathbf{1 0}$ Os cânones interpretativos no processo de construção de normas 11 Conclusão - Referências 


\section{Introdução}

O problema da aplicação normativa e seus métodos representa uma das questões fundamentais da teoria e da filosofia do direito. ${ }^{1}$ No Brasil atual discute-se o papel do método para as ciências jurídicas, especialmente a partir da consideração do "abalo sísmico" sofrido pela metodologia das ciências do espírito (humanas) nas últimas décadas, especialmente na base dos trabalhos da hermenêutica moderna. Teriam os métodos a função de tornar a aplicação normativa um processo objetivo, isento da moral e da subjetividade do intérprete? Seria adequado adotar a postura metodológica do positivismo jurídico especialmente em razão da realidade brasileira? Ou seria melhor acabar de vez com qualquer tipo de "método" dentro do direito? Ao contrário de outros países como a Alemanha, onde esse debate já possui uma tradição centenária, a hermenêutica jurídica tem sido tratada de forma relativamente tímida no Brasil, sendo poucos os pesquisadores que se aprofundam no tema.

Apesar de ter como tarefa final a fixação de uma norma, a conceitualização jurídica ocorre pela compreensão, incluídas nesse processo as atividades interpretativa e especialmente a aplicativa, que em nenhuma outra ciência humana "aparece tanto no primeiro plano como na ciência jurídica" ${ }^{2}$ A aplicação tem especial relevo para o direito porque é nela que os preconceitos do intérprete afloram e norteiam a formação da decisão jurídica, que carece de uma justificação racional para tornar possível seu controle intersubjetivo.

No sentido estrito, a hermenêutica é uma “atividade que, de forma consciente e intencional, dirige-se à compreensão e à explicitação de sentido de uma norma (de um texto)". ${ }^{3}$ No âmbito do discurso prático-jurídico, há necessidade de uma fundamentação explícita que permite o controle intersubjetivo dos enunciados interpretativos que se propõem a justificar a decisão. Assim, a dimensão "preconceituosa" da compreensão que envolve o processo de implementação normativa passa a ser controlável pela coletividade.

Aqueles que interpretam a Constituição podem se considerar intérpretes em sentido estrito, já que exercem a atividade interpretativa em razão da competência (ou função) que Ihes é atribuída: os órgãos estatais, através das atividades

TRIVISONNO, Alexandre T. Gomes. Estudo introdutório: a teoria discursiva do direito de Alexy e as duas questões fundamentais da filosofia do direito. In: ALEXY, Robert. Teoria discursiva do direito. 2. ed. Rio de Janeiro: Forense Universitária, 2015.

2 MÜLLER, Friedrich. Teoria estruturante do direito. Tradução de Peter Naumann e Eurides A. de Souza. 3. ed. São Paulo: RT, 2011. p. 45.

3 HÄBERLE, Peter. Hermenêutica constitucional. A sociedade aberta dos intérpretes da constituição: contribuição para a interpretação pluralista e "procedimental" da constituição. Tradução de Gilmar F. Mendes. Porto Alegre: Sergio Fabris, 2002. p. 13 e ss. 
judicativa, legislativa e administrativa. Em sentido amplo, intérpretes são aqueles que vivenciam a Constituição, que a pré-interpretam, ou aqueles que não são necessariamente órgãos estatais: demandante e demandado; outros integrantes do processo; pareceristas ou experts; representantes de interesses em audiências públicas, associações, partidos políticos, "grupos de pressão" etc. ${ }^{4}$

O sentido mais abrangente do conceito jurídico de interpretação, que engloba o conceito hermenêutico, é exigido pela complexidade do fenômeno do direito. A grande necessidade de se levar em conta o plano intersubjetivo do processo de compreensão que guia a aplicação normativa, representado pelas necessidades tanto da explicitação dos preconceitos de quem decide como de abertura da interpretação normativa à sociedade, e sua estreita relação com a constante busca por previsibilidade e aceitabilidade das decisões jurídicas, por legitimação das ações dos agentes estatais e do próprio Estado, por decisões justas e corretas, demonstram o quão complexo é o fenômeno jurídico. Por isso, o conceito jurídico de interpretação não trabalha apenas com as pretensões de comunicação e de representação de qualquer ação comunicativa, ${ }^{5}$ mas toda interpretação jurídica pretende ser correta, pretende decidir (pôr termo a) um caso prático, pretende gerar ou fundamentar obrigatoriedade, pretende ser justa.

Nesse contexto, procedimentos metódicos ${ }^{6}$ interpretativos têm sua importância realçada especialmente quando representam meios de explicitação, correção e controle dos preconceitos no processo de implementação normativa. Uma hermenêutica (jurídica) crítica, nesse sentido, tem sua importância reconhecida na medida em que desenvolve e realiza mecanismos de exposição e de controle desses preconceitos, para além de sua função eminentemente descritiva do processo de compreensão. Vejamos como a doutrina brasileira mais tradicional lida com a hermenêutica jurídica em geral.

HÄBERLE, Peter. Hermenêutica constitucional. A sociedade aberta dos intérpretes da constituição: contribuição para a interpretação pluralista e "procedimental" da constituição. Tradução de Gilmar F. Mendes. Porto Alegre: Sergio Fabris, 2002. p. 21 e ss.

5 HABERMAS, Jürgen. Verdade e justificação: ensaios filosóficos. Tradução de Milton C. Mota. São Paulo: Loyola, 2004. p. 8 e ss.

6 Distintamente de "metodologia", emprega-se aqui o termo "metódica" no sentido de estudo da relação entre os métodos e a metodologia, de modo que "metódicos" são os procedimentos construídos a partir desse estudo. 


\section{A hermenêutica jurídica na doutrina brasileira tradicional: despreocupação com a metódica interpretativa}

De modo geral, a hermenêutica jurídica possui pouca expressão na doutrina brasileira tradicional, cujos manuais costumam reproduzir textos legais, seguidos da posição da "corrente majoritária”, corroborada ou não por decisões de tribunais. Na prática, alimenta-se uma fé na edição ou modificação de leis como forma de solução para os problemas que surgem da aplicação normativa, em detrimento de soluções hermenêutico-interpretativas. Como saída para os mesmos problemas, a importação acrítica de teorias estrangeiras é bastante comum por parte da doutrina, de maneira tal que muitas vezes teorias já defasadas são adotadas como “modernas", mesmo quando já reformuladas em seus países de origem.

Nessa esteira, a discricionariedade jurídica (judicial e administrativa) ainda é vista como um mal a ser evitado, fato que tem levado a uma indevida redução do controle judicial de situações em que este controle seria possível e necessário. De um lado, grande parte da doutrina e da jurisprudência adota a já ultrapassada teoria alemã da classificação qualitativa dos atos administrativos (em vinculados ou discricionários), que, ao invés de solucionar o problema do decisionismo e do subjetivismo, acaba limitando a possibilidade de exposição dos motivos em torno da decisão administrativa. Do outro lado, a discricionariedade judicial é comumente relacionada ao subjetivismo, à arbitrariedade e à insegurança jurídica, de modo que a prática judicial tem "solucionado" os problemas que surgem da aplicação de conceitos jurídicos indeterminados através de posturas abstencionistas, em casos nos quais, muitas vezes, a intervenção do Judiciário seria necessária e não representaria nenhuma "usurpação" da competência dos outros poderes. Esses são bons exemplos de certa inabilidade brasileira em lidar com questões que exigem soluções hermenêuticas mais complexas e detalhadas.

Respostas para esse problema têm sido apontadas pela doutrina especializada, que sugere como ponto de partida a teoria alemã mais atual sobre os conceitos jurídicos indeterminados, já com aceitação na doutrina pátria, e justifica seu emprego também para a realidade brasileira. A ideia básica dessa teoria é a de que a utilização de conceitos indeterminados nos textos legais pelo legislador e a concessão de discricionariedade administrativa devem ser vistas como manifestações comuns da técnica legislativa de abertura das normas jurídicas, carecedoras de complementação, ${ }^{7}$ considerando a indissociável dimensão volitiva

Vide a respeito KRELL, Andreas J. Discricionariedade administrativa e conceitos legais indeterminados: limites do controle judicial no âmbito dos interesses difusos. 2. ed. Porto Alegre: Livraria do Advogado, 2013. p. 33 e ss. 
(não meramente cognitiva) da aplicação normativa, representada pela atividade criativa do intérprete, já reconhecida mesmo por Kelsen. ${ }^{8}$

A discricionariedade como técnica jurídica permite que, uma vez reconhecida a ampla e inevitável dimensão criativa (volitiva e necessariamente preconceituosa) da atividade de implementação normativa, desenvolvam-se mecanismos mais complexos de exposição, correção e de controle das decisões jurídicas, que consigam trabalhar com a maior ou menor densidade normativa dos textos legais, com as diversas dimensões da linguagem e dos preconceitos do intérprete.

Por outro lado, essa necessidade de se levar em conta a dimensão intersubjetiva do processo de compreensão que envolve a decisão jurídica não passou despercebida pela prática judicial dos tribunais superiores, especialmente do STF e do STJ. Reconhecendo a necessidade de abertura do processo de interpretação da Constituição para a sociedade, esses tribunais incorporaram à sua jurisprudência o amicus curiae e as audiências públicas, que tentam assegurar a participação popular no processo de concretização da Constituição. ${ }^{9}$ Apesar de iniciativas como essas representarem os primeiros passos de uma mudança no pensamento jurídico brasileiro, seus reais efeitos só poderão ser percebidos na medida em que a participação dos sujeitos que pré-interpretam a Constituição seja explicitamente considerada na justificação das decisões desses tribunais, como uma garantia procedimental de participação interpretativa.

Não obstante, a hermenêutica jurídica ainda aparece na doutrina tradicional e na grade curricular dos cursos de direito como uma atividade distante, por vezes limitada à ideia de interpretação reservada a questões que surgiriam apenas nos casos difíceis, quando o ordenamento jurídico não oferece uma "resposta pronta", ou quando o texto é obscuro ou contraditório. Ela costuma ser tratada com mais afinco no que se refere ao trato com a Constituição, enquanto as peculiaridades da interpretação das normas ordinárias ficam em segundo plano. Esse contexto permite que a estrutura específica das normas de subsistemas jurídicos e sua densidade normativa passem despercebidas tanto no debate acadêmico quanto na aplicação normativa.

Boa parte dessa situação de “descaso hermenêutico" se deve às heranças do positivismo jurídico, que foram acentuadas durante a Ditadura Militar de 1964. Nessa época, as influências do positivismo lógico na aplicação normativa foram intensificadas sob a roupagem de um tecnicismo formalista que sobrevalorizava

8 KELSEN, Hans. Teoria pura do direito. Tradução de João Baptista Machado. 8. ed. São Paulo: Martins Fontes, 2009. p. 393 e ss.

9 Cf. MENDES, Gilmar Ferreira; VALE, André Rufino do. O pensamento de Peter Häberle na jurisprudência do STF. Observatório da Jurisdição Constitucional, Brasília, ano 2, 2008/2009. 
a lógica no trato com textos legais. Essa postura excessivamente textualista resumia a aplicação normativa ao método da subsunção. ${ }^{10}$

Assim, o estudo da hermenêutica tem ficado adstrito à doutrina especializada, mais distante das graduações. Isso tem contribuído para uma espécie de ceticismo interpretativo da prática e para o enfraquecimento da dogmática jurídica, principalmente nas áreas menos tradicionais do direito brasileiro (ambiental, por exemplo). Esses problemas também influem negativamente na forma de lidar com o método jurídico, que tem servido para a teoria brasileira como uma espécie de "bode expiatório" de críticas cujos alvos são, na verdade, o positivismo jurídico e a injustiça legal, de um lado, e a "arbitrariedade" e a insegurança jurídica, do outro. Parte dessas críticas será brevemente analisada a seguir, tanto as que atacam o método jurídico em geral, como as que especificamente atingem os chamados métodos clássicos da interpretação, com destaque aos cânones interpretativos.

Em outros países, como na Alemanha, os métodos clássicos de interpretação jurídica vêm passando por uma reabilitação que busca a maior racionalização possível do processo de produção normativa. No Brasil, apesar de constantemente utilizados pela prática jurídica, eles sofrem fortes críticas de parte da doutrina, que em muitas vezes assume uma postura cética quanto à sua contribuição para a aplicação normativa. Nos manuais jurídicos mais tradicionais, os métodos interpretativos costumam ser subestimados: a maioria nem faz referência aos cânones interpretativos, nem a formas de resolução de conflitos entre normas principiológicas. ${ }^{11}$ Outros, apesar de mencioná-los, não os desenvolvem; ${ }^{12}$ poucos são os que reconhecem sua importância e os tratam com mais rigor. ${ }^{13}$

Por outro lado, os cânones interpretativos estão presentes na prática judicial com uma frequência e uma importância que não podem ser relegadas pela teoria. Seria difícil imaginar um controle de constitucionalidade ou uma “interpretação conforme à Constituição"14 que não envolvesse interpretações sistemáticas, ou teleológicas. A cláusula geral da responsabilidade civil objetiva (art. 927, parágrafo único, Código Civil) ficaria, igualmente, sem aplicabilidade prática se não fosse

10 SOUZA NETO, Claudio Pereira de; SARMENTO, Daniel. Direito constitucional: teoria, história e métodos de trabalho. Belo Horizonte: Fórum, 2012. p. 392 e ss.

11 Cf. MORAES, Alexandre de. Direito constitucional. 27. ed. São Paulo: Atlas, 2011; SILVA, José Afonso da. Curso de direito constitucional positivo. 35. ed. São Paulo: Malheiros, 2012.

12 CUNHA JÚNIOR, Dirley da. Curso de direito constitucional. 5. ed. Salvador: JusPodivm, 2011. p. 216 e Ss.; MENDES, Gilmar Ferreira; BRANCO, Paulo Gustavo Gonet. Curso de direito constitucional. 8. ed. São Paulo: Saraiva, 2013. p. 91 e ss.

13 Cf. BONAVIDES, Paulo. Curso de direito constitucional. 30. ed. São Paulo: Malheiros, 2015. p. 447 e ss.; SOUZA NETO, Claudio Pereira de; SARMENTO, Daniel. Direito constitucional: teoria, história e métodos de trabalho. Belo Horizonte: Fórum, 2012. p. 410 e ss.

14 MENDES, Gilmar Ferreira; BRANCO, Paulo Gustavo Gonet. Curso de direito constitucional. 8. ed. São Paulo: Saraiva, 2013. p. 1267 e ss. 
conjugada com o restante do ordenamento, especialmente com o ordenamento constitucional. É bem verdade que na "interpretação da Constituição, a importância dos métodos tradicionais, sem dúvida, diminui”, principalmente em razão da dimensão política das normas constitucionais, que acaba ampliando as pretensões da sua aplicação. Mas, antes de representar uma pretensa necessidade de sua extinção, isso significa que, sozinhos, eles não devem orientar a interpretação da Constituição. ${ }^{15}$

Com o advento da reviravolta linguístico-pragmática, ${ }^{16}$ que enfatiza o caráter circunstancial da constituição semântica do sentido, construído mediante "jogos de linguagem" (Wittgenstein) e não a partir de uma pretensa "essência" das palavras, o próprio método passou a ser questionado. Especialmente na área do direito, não se fala mais em objetividade, universalidade e certeza metodológicas, que ficaram restritas ao âmbito das ciências naturais (exatas). Por consequência, a ciência jurídica não busca (mais) a verdade objetiva, alcançável por um método universal. Ao mesmo tempo, não cabe proclamar a inutilidade dos métodos jurídicos, que ainda possuem uma importante função para o direito, auxiliando na construção e aplicação normativas, seja como diretivas interpretativas, seja como "boas razões" da argumentação discursiva. No Brasil, contudo, não são poucos os autores que negam ao método qualquer espaço dentro do discurso jurídico, como será visto em seguida.

\section{As críticas mais comuns contra os cânones interpretativos}

A partir das filosofias de Heidegger e de Gadamer, Streck faz fortes críticas à metódica jurídica, afirmando que “os métodos de interpretação podem ser considerados o álibi teórico para emergência das crenças que orientam a aplicação do Direito" ${ }^{17}$ O uso dos métodos de interpretação representaria a não recepção do giro linguístico pela hermenêutica brasileira, fazendo com que os cânones interpretativos levassem a um "fatiamento" do processo de interpretação, que não poderia ser feito por representar um momento unitário da compreensão originária. ${ }^{18}$ Responsabilizando o "esquema sujeito-objeto", oriundo das ciências naturais, e a herança da filosofia da consciência, que ainda dominariam o imaginário dos

15 Cf. BONAVIDES, Paulo. Curso de direito constitucional. 30. ed. São Paulo: Malheiros, 2015. p. 470 e ss.

16 OLIVEIRA, Manfredo Araújo de. Reviravolta linguístico-pragmática na filosofia contemporânea. 4. ed. São Paulo: Loyola, 2015. p. 117 e ss.

17 STRECK, Lenio L. Hermenêutica jurídica $e(m)$ crise: uma exploração hermenêutica da construção do direito. 4. ed. Porto Alegre: Livraria do Advogado, 2003. p. 109 e ss. Grifos no original.

18 STRECK, Lenio L. Hermenêutica jurídica $e(m)$ crise: uma exploração hermenêutica da construção do direito. 4. ed. Porto Alegre: Livraria do Advogado, 2003. p. 79. 
operadores do direito, pela má aplicação das leis pátrias, Streck também acusa a principiologia e a ponderação pelas arbitrariedades cometidas pelos julgadores. A própria "irracionalidade da fórmula"19 da ponderação ficaria patente pelo fato de ela permitir diferentes soluções para o mesmo caso.

Para Streck, as críticas que Gadamer faz à transposição da metodologia de matiz cartesiana ao contexto das ciências humanas valeriam para qualquer postura metódica, ainda que mais distante das pretensões de universalidade, de objetividade e de certeza das ciências naturais. Ele afirma que a obra Verdade e método, de Gadamer, sugere que não haveria qualquer relação entre a verdade e o método, pois este serviria apenas para encobrir a subjetividade dos intérpretes, devendo o título da obra ser entendido como "verdade contramétodo". ${ }^{20}$ Esta posição radical, contudo, desconsidera as funções do método além daquelas visadas pelas ciências naturais. O próprio Gadamer julga importante o aperfeiçoamento de um pensamento metodológico para a hermenêutica, posicionando-se apenas contra o emprego da metodologia cartesiana nas ciências do espírito. Esta rejeição não abrange uma metódica jurídica que observe as principais conclusões da hermenêutica filosófica em relação ao processo de compreensão.

Ainda que os métodos não guardassem qualquer relação com a verdade - por integrarem o chamado "logos apofântico", ${ }^{21}$ externo à compreensão "originária" (hermenêutica) -, eles ainda exerceriam a função de explicitar e organizar informações, motivos e preconceitos, a partir de uma estruturação racional, privilegiando, assim, o plano intersubjetivo da construção linguística da materialidade. ${ }^{22}$ Neste sentido, Müller se opõe ao positivismo jurídico sustentando ser inviável uma metodologia de interpretação e aplicação do direito que tenha como referência uma "unidade de sentido dos elementos da ordem jurídica e das ordens extrajurídicas", dada a impossibilidade de separar rigorosamente direito e realidade na aplicação normativa. ${ }^{23}$

A metódica interpretativa no sentido aqui defendido é capaz de conjugar elementos jurídicos e extrajurídicos de maneira racional, tendo em vista que o "afastamento dos métodos do positivismo, compreendidos como absolutos, não

19 STRECK, Lenio L. Verdade e consenso: Constituição, hermenêutica e teorias discursivas. 5. ed. São Paulo: Saraiva, 2014. p. 59 e ss.

20 STRECK, Lenio L. Hermenêutica jurídica $e(m)$ crise: uma exploração hermenêutica da construção do direito. 4. ed. Porto Alegre: Livraria do Advogado, 2003. p. 218; STRECK, Lenio L. Verdade e consenso: Constituição, hermenêutica e teorias discursivas. 5. ed. São Paulo: Saraiva, 2014. p. 25; 303 e ss.

21 STRECK, Lenio L. Verdade e consenso: Constituição, hermenêutica e teorias discursivas. 5. ed. São Paulo: Saraiva, 2014. p. 304.

22 MÜLLER, Friedrich. Teoria estruturante do direito. Tradução de Peter Naumann e Eurides A. de Souza. 3. ed. São Paulo: RT, 2011. p. 65; 75 e ss.

23 MÜLLER, Friedrich. Teoria estruturante do direito. Tradução de Peter Naumann e Eurides A. de Souza. 3. ed. São Paulo: RT, 2011. p. 37 e ss. 
precisa levar ao seu banimento da ciência jurídica", sendo "mais recomendável reconhecê-los na sua legitimidade relativa e utilizá-los, no âmbito dessa relativização, na aplicação do direito com intenção racionalizadora". ${ }^{24}$ Mesmo no plano da compreensão originária, os métodos podem passar a integrar as preconcepções dos intérpretes, ainda que contingencialmente, influindo no "acontecimento da verdade" em dada tradição. Nesse sentido, a relação entre o método e a verdade resta estabelecida, e a real dificuldade se mostra no amadurecimento de uma consciência metódica que saiba lidar com preconcepções voltadas à construção intersubjetiva da materialidade, e no aperfeiçoamento das estruturas metódicas que poderão integrar a pré-compreensão dos intérpretes.

Os cânones interpretativos são um exemplo, cuja estrutura representa processos interpretativos ordinários, realizados na aplicação normativa cotidianamente, que passaram a integrar a tradição jurídica e os preconceitos dos juristas de maneira consciente há bastante tempo. Dada a constante necessidade de referência a um caso prático, essas estruturas representam tentativas de "apreensão e enquadramento" da materialidade em determinadas direções (histórica, finalística, dos usos linguísticos etc.), voltadas à construção das premissas normativas e fáticas e à justificação de sua conclusão. ${ }^{25}$

A necessidade de fundamentação do conteúdo dessas "incursões na materialidade" não torna inócuo o método interpretativo, nem o transforma em “álibi teórico" para a subjetividade, mas resulta da intangibilidade direta da materialidade, cuja apreensão correta depende menos de esforços e percepções individuais ou da pré-compreensão em si, do que de uma construção linguística intersubjetivamente controlável. Nesse sentido, há de se reconhecer que os "fatos são construídos pela mediação do discurso do intérprete" e que "a existência mesma do fato não depende da experiência, mas da argumentação". ${ }^{26}$ Antes de fórmulas prontas para serem empregadas, os cânones são indicativos de linhas argumentativas que podem ser individualmente mais ou menos importantes a depender dos anseios do caso concreto. ${ }^{27}$

Assim, uma argumentação que leve em conta o contexto histórico em torno da elaboração de um preceito normativo deve indicar por que ou como o ponto de vista histórico, das emendas rejeitadas em comparação com as aprovadas ao

24 MÜLLER, Friedrich. Teoria estruturante do direito. Tradução de Peter Naumann e Eurides A. de Souza. 3. ed. São Paulo: RT, 2011. p. 77.

25 ENGISCH, Karl. Introdução ao pensamento jurídico. Tradução de João Baptista Machado. 10. ed. Lisboa: Fundação Calouste Gulbenkian, 2008. p. 115 e ss.

26 ÁVILA, Humberto. Teoria dos princípios: da definição à aplicação dos princípios jurídicos. 15. ed. São Paulo: Malheiros, 2014. p. 125 e ss.

27 MÜLLER, Friedrich. Teoria estruturante do direito. Tradução de Peter Naumann e Eurides A. de Souza. 3. ed. São Paulo: RT, 2011. p. 90. 
decorrer do processo legislativo, por exemplo, é juridicamente capaz de sustentar a proposta de resolução do caso que se tornará definitiva com a decisão, conjugando-se outras formas normativas e empíricas de argumento na formulação da resposta. É o que se chama de "requisito da saturação", em que os argumentos que sustentam um enunciado carecem da complementação de outras formas de argumentos. ${ }^{28}$

Nesse sentido, os métodos jurídicos servem como boas razões no processo discursivo de uma argumentação. Para o direito, o método tem função racional, expositiva e organizativa, instrumental às pretensões de fundamentabilidade, de correção, de decidibilidade e de obrigatoriedade, inerentes à aplicação normativa. ${ }^{29}$ O fato de muitas vezes a invocação desses métodos gerar interpretações arbitrárias costuma ter causas das mais variadas; o seu emprego guarda uma relação muito distante com a herança da filosofia da consciência. A origem dessas distorções normalmente reside na má-compreensão da função dos métodos invocados, encoberta pelo problema da fundamentação deficiente das decisões jurídicas. $\mathrm{Na}$ verdade, este modelo cultural de justificação é o grande problema da aplicação normativa no Brasil. ${ }^{30}$

Por isso, parecem ser mais produtivas e apropriadas para o contexto brasileiro maneiras menos radicais de lidar com os métodos, especialmente com os cânones clássicos do direito. Antes da supressão destes, deverá haver um amadurecimento da própria consciência metodológica e um aperfeiçoamento da metódica interpretativa.

\section{Os cânones interpretativos e a racionalidade discursiva}

Deixada de lado a pretensão de uma verdade objetiva para o método jurídico, faz-se necessária a consideração dos quatro cânones orientados pela "intenção racionalizadora" de Müller, ou postos como referência dentro da argumentação discursiva de uma decisão jurídica que se pretende justa ou correta. ${ }^{31}$ Nesse contexto, o termo método não conserva o sentido de “caminho para a verdade

28 ALEXY, Robert. Teoria da argumentação jurídica: a teoria do discurso racional como teoria da fundamentação jurídica. Tradução de Zilda H. Schild Silva. 3. ed. Rio de Janeiro: Forense, 2013. p. 241 e ss.

29 Cf. ALEXY, Robert. Teoria da argumentação jurídica: a teoria do discurso racional como teoria da fundamentação jurídica. Tradução de Zilda H. Schild Silva. 3. ed. Rio de Janeiro: Forense, 2013. p. 130 e ss.

30 No mesmo sentido, RODRIGUEZ, José Rodrigo. Como decidem as cortes? - Para uma crítica do direito (brasileiro). Rio de Janeiro: FGV, 2013. p. 70 e ss.

31 ALEXY, Robert. Teoria da argumentação jurídica: a teoria do discurso racional como teoria da fundamentação jurídica. Tradução de Zilda H. Schild Silva. 3. ed. Rio de Janeiro: Forense, 2013. p. 245. 
objetiva"; antes, os cânones interpretativos devem ser vistos como regras, diretivas, técnicas, critérios, argumentos, ou elementos metódicos para a adequada interpretação e aplicação das normas jurídicas.

As citadas funções dos cânones metódicos também ganham relevo frente à realidade jurídica brasileira, na qual a aplicação normativa ainda é marcada por um pensamento textualista, de matiz lógico-positivista, e por um ceticismo interpretativo que alimenta a inflação legislativa, causada pela fé na edição de leis como solução para problemas prático-jurídicos. Estes fatores terminam privilegiando argumentos de autoridade, em detrimento da exposição dos dados que envolvem as decisões jurídicas. Por isso, seria preciso uma metódica jurídica atenta às discussões hermenêuticas e à própria realidade brasileira. ${ }^{32}$ Assim, é imprescindivel situar os cânones interpretativos no contexto do discurso racional após a virada linguística.

Desde sua canonização no século XIX por Savigny, os métodos interpretativos clássicos são chamados de "elementos" da interpretação, como forma de destacar que não se trata estritamente de métodos que se propõem a hierarquizar e manusear os momentos da interpretação, mas sim de critérios que direcionam o jurista a fazer determinadas perguntas, que terão um peso distinto a depender do caso concreto. ${ }^{33}$ Do ponto de vista da hermenêutica filosófica, essas perguntas atenderiam à função de suspensão da validade dos preconceitos do jurista para sua verificação no plano individual da compreensão. Já no plano coletivo a estrutura da pergunta seria inócua se não representasse uma tentativa de abertura da pré-compreensão individual para a intersubjetividade, através da exposição das informações de que dispunha o intérprete no momento da aplicação normativa. Tal exposição tornaria o "acontecimento da verdade" no plano intersubjetivo no mínimo potencial.

O direcionamento temático prévio, estruturado pelos cânones, não quer ofender a compreensão originária com pretensões objetivadoras, "fatiando a interpretação", mas pretende delimitar o conteúdo de perguntas que podem ser feitas pelo intérprete ao se deparar com um caso concreto. Toda pergunta já pressupõe uma delimitação temática, e por isso proporciona uma abertura de sentidos apenas relativa. O direcionamento temático orientado pelos cânones representa questionamentos que podem ser importantes para justificar a aplicação

32 RODRIGUEZ, José Rodrigo. Como decidem as cortes? - Para uma crítica do direito (brasileiro). Rio de Janeiro: FGV, 2013. p. 62 e ss.

33 BARROSO, Luis Roberto. Interpretação e aplicação da Constituição: fundamentos de uma dogmática constitucional transformadora. 7. ed. São Paulo: Saraiva, 2014. p. 129; PEIXINHO, Manoel Messias. A interpretação da Constituição e dos princípios fundamentais: elementos para uma hermenêutica constitucional renovada. 3. ed. Rio de Janeiro: Lumen Juris, 2003. p. 32. 
concreta de uma norma. Enquanto formas de argumento do discurso racional, os cânones permitem que o processo de elaboração das perguntas e respostas seja racionalmente explicitado e estruturado.

Ainda que os argumentos sejam expostos estrategicamente na fundamentação de um resultado pré-selecionado, eles estarão expostos, aptos, portanto, a serem intersubjetivamente controlados. Isso não quer dizer que haverá um maior subjetivismo, decisionismo, arbitrariedade ou insegurança jurídica, ideias alimentadas pela utopia da neutralidade do aplicador da lei, que se isentaria de qualquer parcialidade obedecendo ao sentido literal do texto, num processo "lógico" que permitiria uma maior previsibilidade da decisão final. Pelo contrário, além desses conceitos estarem ligados à herança do positivismo lógico e do racionalismo iluminista, eles alimentam o mesmo pensamento metodológico que sustenta o modelo brasileiro de fundamentação das decisões jurídicas, em que ementas de outras decisões muitas vezes atuam como único fundamento da decisão e a doutrina é citada apenas para reafirmar a autoridade do juiz, sem qualquer articulação com o caso concreto. ${ }^{34}$

A falsa ideia de estrita e permanente vinculação ao teor literal da lei, guiada pelo antigo modelo de tripartição de poderes do Estado Liberal burguês, permite que os preconceitos fiquem encobertos, enquanto o intérprete, muitas vezes crente de que está “apenas seguindo a lei”, guia sua decisão entre dois extremos: ou deixa sua posição em aberto sob a escusa de que estaria respeitando a competência dos outros poderes, num verdadeiro ato de non liquet, ou toma a materialidade para si sob uma pretensa "evidência" ou "clareza”, que, além de muitas vezes só existir para ele, na prática serve como uma escusa de motivação da própria decisão, ainda que essa "clareza" seja orientada pelas melhores intenções do aplicador.

Do ponto de vista da teoria da racionalidade discursiva, a exposição metódica das razões de quem decide permite uma justificação mais complexa da decisão jurídica e das interpretações que a envolvem, ampliando as possibilidades de controle e de conformação intersubjetivos. ${ }^{35}$ A racionalização desse processo de exposição atende às pretensões de ciência do direito e é capaz de aproximar a teoria da realidade prática, organizando e padronizando a tarefa expositiva, que,

34 BARROSO, Luis Roberto; BARCELLOS, Ana Paula de. O começo da história: a nova interpretação constitucional e o papel dos princípios no direito brasileiro. In: SILVA, Virgílio Afonso da (Org.). Interpretação constitucional. São Paulo: Malheiros, 2010. p. 293 e ss.; RODRIGUEZ, José Rodrigo. Como decidem as cortes? - Para uma crítica do direito (brasileiro). Rio de Janeiro: FGV, 2013. p. 59 e ss.

35 MÜLLER, Friedrich. Teoria estruturante do direito. Tradução de Peter Naumann e Eurides A. de Souza. 3. ed. São Paulo: RT, 2011. p. 28 e ss. 
racionalizada, terá a feição de uma justificação. ${ }^{36}$ Apesar das tentativas de afirmar uma hierarquia entre os cânones, não há parâmetro seguro para estabelecê-la; sua maior ou menor importância pode ser determinada apenas na medida em que cada um contribuiu para a resolução do caso concreto. ${ }^{37}$

Em seguida, far-se-á um breve exame dos cânones interpretativos mais relevantes para o processo de aplicação normativa, com o intuito de compreender sua relatividade e sua importância nesse processo. Serão abordados os cânones mais tradicionais da doutrina moderna: gramatical, sistemático, histórico e teleológico. Apenas os primeiros três foram canonizados por Savigny; o elemento teleológico, desde Ihering, adquiriu importância para a maioria dos autores, principalmente frente ao discurso racionalista. ${ }^{38}$

\section{Os elementos literal e sistemático}

O elemento literal - também chamado de gramatical, semântico ou filológico direciona a pergunta do intérprete para o sentido das palavras contidas no texto legal. Com esse elemento, haverá uma tensão entre as duas tendências "de fazer prevalecer o sentido natural e corrente da linguagem" e "de privilegiar o sentido técnico-jurídico da mesma linguagem". ${ }^{39}$ Apesar de o sentido corrente dos termos ter sua importância considerada, através da experiência do intérprete enquanto falante daquela língua, ele muitas vezes não é capaz de determinar a interpretação adequada do texto legal, já que o legislador se vale com frequência de uma artificialidade linguística na elaboração das leis, empregando termos jurídicos técnicos, com sentidos mais ou menos específicos, que exigem uma atividade construtiva mais intensa.

Em qualquer caso, haverá sempre uma vinculação ao texto legal, enquanto expressão da vontade democrática. Este vínculo, contudo, é relativo. Em numerosos casos o sentido literal de um texto, além de ser determinável com facilidade, oferece respostas não contraditórias, justas, ou plausíveis ao caso

36 MÜLLER, Friedrich. Teoria estruturante do direito. Tradução de Peter Naumann e Eurides A. de Souza. 3. ed. São Paulo: RT, 2011. p. 83-93.

37 SOUZA NETO, Claudio Pereira de; SARMENTO, Daniel. Direito constitucional: teoria, história e métodos de trabalho. Belo Horizonte: Fórum, 2012. p. 410.

38 Cf. BARROSO, Luis Roberto. Interpretação e aplicação da Constituição: fundamentos de uma dogmática constitucional transformadora. 7. ed. São Paulo: Saraiva, 2014. p. 129 e ss.; SOUZA NETO, Claudio Pereira de; SARMENTO, Daniel. Direito constitucional: teoria, história e métodos de trabalho. Belo Horizonte: Fórum, 2012. p. 410.

39 ENGISCH, Karl. Introdução ao pensamento jurídico. Tradução de João Baptista Machado. 10. ed. Lisboa: Fundação Calouste Gulbenkian, 2008. p. 138. 
concreto, de modo que a conclusão final pode ser juridicamente deduzida ${ }^{40}$ das premissas normativas e fáticas sem maiores problemas. Todavia, há também muitas situações em que o sentido literal da lei não permite que se chegue a soluções adequadas, não contraditórias ou justas para os casos concretos. Outras vezes, é quase impossível identificar um sentido literal claro, tal quando se lida com conceitos jurídicos indeterminados, como "crueldade" (art. 225, VII, CF) ou "extensão do dano" (art. 944, caput, CC) nas hipóteses de dano extrapatrimonial. Nesses casos, a própria formação das premissas normativas e fáticas se torna uma atividade mais difícil, e a justificação da sua conclusão exige uma mais complexa atuação do intérprete. Essa situação faz da vinculação ao "sentido literal" da lei uma ficção.

Enquanto diretiva interpretativa, o teor literal do texto legal tem uma importância relativa, uma vez que ele não é unitário, objetivo, extraível da "essência das palavras", senão um sentido instável e provisório, dependente da historicidade da linguagem. Assim, constitui um fator contingente a maneira como os conceitos jurídicos se comportam frente ao caso concreto, além dos preconceitos do intérprete cujo conteúdo é sempre limitado por suas possibilidades individuais e escolhas interpretativas. ${ }^{41}$ Essa relatividade destaca a importância da diferenciação entre texto e norma, de que depende a atividade interpretativa, e realça a necessidade de se levar a sério a discricionariedade jurídica, resultado incontornável da dimensão artificial $^{42}$ da linguagem, que é acentuada nos termos técnico-jurídicos.

Por essas razões, a “interpretação gramatical não leva, no mais das vezes, a decisões unívocas: produz um número maior ou menor de possibilidades interpretativas, e o intérprete tem de optar por uma em detrimento das demais, considerando outros critérios". ${ }^{43}$ Estes têm a forma de argumentos que juntos se complementam, formando uma teia mais ou menos densa de enunciados que podem ser discutidos e problematizados intersubjetivamente. Frente à relatividade do teor literal da lei, a argumentação racional tem sua importância garantida na

40 Para o conceito de dedutividade jurídica, cf. ALEXY, Robert. Teoria da argumentação jurídica: a teoria do discurso racional como teoria da fundamentação jurídica. Tradução de Zilda H. Schild Silva. 3. ed. Rio de Janeiro: Forense, 2013. p. 219 e ss.; ATIENZA, Manuel. As razões do direito: teoria da argumentação jurídica. Tradução de Maria Cristina G. Cupertino. 2. ed. Rio de Janeiro: Forense Universitária, 2014. p. 15 e ss.

41 ENGISCH, Karl. Introdução ao pensamento jurídico. Tradução de João Baptista Machado. 10. ed. Lisboa: Fundação Calouste Gulbenkian, 2008. p. 139.

42 Sobre a artificialidade dos termos linguístico-científicos, cf. GADAMER, Hans-Georg. Verdade e método l: traços fundamentais de uma hermenêutica filosófica. Tradução de Flávio P. Meurer. 14. ed. Petrópolis: Vozes, 2014. p. 536 e ss.

43 SOUZA NETO, Claudio Pereira de; SARMENTO, Daniel. Direito constitucional: teoria, história e métodos de trabalho. Belo Horizonte: Fórum, 2012. p. 412. 
medida em que permite que as escolhas interpretativas do aplicador da lei sejam expressas em formas de argumentos, que carecerão de uma complementação por outros critérios. ${ }^{44}$ Quanto mais o intérprete se distancia da literalidade do texto, maior é o ônus argumentativo que ele assume, de modo que a necessidade de complementação dos seus argumentos por outros critérios será maior. Entre esses critérios estão os demais elementos interpretativos.

Tendo em vista que os conceitos legais fazem parte de um complexo ordenamento jurídico, representado por uma unidade sistematicamente organizada, o elemento sistemático direciona o intérprete a perguntar pelo sentido da norma como integrante desse ordenamento. Esse elemento representa as exigências de coerência, a partir de uma estrutura interna de referência, e de consistência, ou ausência de contradições. Assim, "cada norma jurídica deve ser interpretada em consideração de todas as demais, e não de forma isolada”, a partir tanto do ponto topográfico da norma dentro do ordenamento, como da harmonia lógicoteleológica entre essa norma e o sistema. ${ }^{45}$

Principalmente em razão de sua superioridade hierárquica, a Constituição assume uma posição fundamental frente ao sistema jurídico como um todo, e, consequentemente, frente à construção das normas individuais de cada caso concreto. A dimensão objetiva dos direitos fundamentais vincula os três poderes de maneira imediata (art. 5ํㅗ $\left.\S^{1}{ }^{\circ}, C F\right) .{ }^{46}$ Isso significa que a interpretação de cada norma deve observar o caráter vinculatório dos direitos fundamentais tanto na escolha e valoração das normas (regras e princípios) e fatos que determinarão as premissas normativas e fáticas, quanto na justificação da conclusão dessas premissas. ${ }^{47}$

Para a tarefa interpretativa do Poder Judiciário, essa vinculação tem um significado mais procedimental frente à dimensão objetiva dos direitos fundamentais, no sentido de que o aplicador deve demonstrar, através de um procedimento de justificação, como considerou as diversas conexões e implicações entre o sistema jurídico, as normas aplicáveis, os elementos fáticos relevantes para o caso

44 ALEXY, Robert. Teoria da argumentação jurídica: a teoria do discurso racional como teoria da fundamentação jurídica. Tradução de Zilda H. Schild Silva. 3. ed. Rio de Janeiro: Forense, 2013. p. 243.

45 SOUZA NETO, Claudio Pereira de; SARMENTO, Daniel. Direito constitucional: teoria, história e métodos de trabalho. Belo Horizonte: Fórum, 2012. p. 415.

46 MENDES, Gilmar Ferreira; BRANCO, Paulo Gustavo Gonet. Curso de direito constitucional. 8. ed. São Paulo: Saraiva, 2013. p. 147 e ss.; 167 e ss.

47 Cf. ALEXY, Robert. Teoria dos direitos fundamentais. Tradução de Virgílio Afonso da Silva. 2. ed. São Paulo: Malheiros, 2014. p. 499-519; ÁVILA, Humberto. Teoria dos princípios: da definição à aplicação dos princípios jurídicos. 15. ed. São Paulo: Malheiros, 2014. p. 125 e ss. 
concreto e suas próprias valorações conceituais, expondo o caminho percorrido até a sua decisão. ${ }^{48}$

A partir do elemento sistemático, é possível que se construam soluções para quando o sentido literal do texto é insuficiente ou inexistente sem perder referência legal, ou "vinculação à lei". Nessa esteira, a presença de um termo jurídico indeterminado vai exigir que se recorra, entre outras coisas, à Constituição, aos princípios que sustentam as posições em questão. Para se chegar a um sentido constitucional e sistematicamente adequado do termo, que seja passível de subsunção, eventual ponderação entre os diferentes valores e interesses deverá ser feita com referência às relações concretas de sentido, aquelas presentes no caso concreto. ${ }^{49}$

Observadas as regras do discurso jurídico-racional, não há que se falar de irracionalidade da ponderação pelo simples fato de ela permitir resultados diferentes, uma vez que "as regras do discurso jurídico permitem que seus vários participantes cheguem a soluções incompatíveis entre si, mas racionais (i.e., fundamentadas discursivamente)". ${ }^{50} \mathrm{Em}$ geral, pode-se afirmar que a teoria do discurso jurídico racional não está em busca de um único resultado correto do ponto de vista teorético-decisório, mas estabelece critérios negativos para a racionalidade do processo de decisão jurídica, isto é, ela identifica o que não se pode fazer quando se pretende que um discurso seja minimamente racional. ${ }^{51}$

Quando se toma como referência argumentativa, por exemplo, o local do sistema jurídico em que o legislador posicionou o texto da norma ao se interpretar a hipótese de aborto (art. 124, Código Penal - CP) em razão de fetos anencéfalos como um crime contra a vida (Cap. I, do Título I, do CP), o conceito de vida ganha uma importância essencial para a fixação e subsunção das premissas de um caso concreto. Numa hipótese como essa, um argumento sistemático-teleológico pode ser sustentado no sentido de que a localização dos referidos dispositivos dá indícios de que o legislador tinha como finalidade proteger menos valores morais e religiosos do que a vida, inexistente para um feto anencéfalo do ponto de vista

48 ALEXY, Robert. Teoria dos direitos fundamentais. Tradução de Virgílio Afonso da Silva. 2. ed. São Paulo: Malheiros, 2014. p. 516.

49 ÁVILA, Humberto. Teoria dos princípios: da definição à aplicação dos princípios jurídicos. 15. ed. São Paulo: Malheiros, 2014. p. 185 e ss.

50 ATIENZA, Manuel. As razões do direito: teoria da argumentação jurídica. Tradução de Maria Cristina G. Cupertino. 2. ed. Rio de Janeiro: Forense Universitária, 2014. p. 213 e ss.

51 ALEXY, Robert. Teoria da argumentação jurídica: a teoria do discurso racional como teoria da fundamentação jurídica. Tradução de Zilda H. Schild Silva. 3. ed. Rio de Janeiro: Forense, 2013. p. 284 e Ss.; ALEXY, Robert. Teoria discursiva do direito. Tradução de Alexandre Travessoni Gomes Trivisonno. 2. ed. Rio de Janeiro: Forense Universitária, 2015. p. 40 e ss. 
do conhecimento científico atual, que leva em consideração o conceito de vida/ morte encefálica, acolhido pela Lei de Transplante de Órgãos (Lei no 9.434/97). ${ }^{52}$

Considerando que a referência entre a norma interpretada e o ordenamento jurídico como um todo é, em boa medida, finalística, no sentido de que se busca conectar ambos (norma e sistema) também a partir de seus fins, Engisch afirma como custosa a separação entre o elemento sistemático e o elemento teleológico. Isso porque as normas jurídicas “têm em grande parte por função preencher certos fins em combinação com outras normas, completar finalisticamente essas outras normas". 53

Também para Alexy, o argumento sistemático engloba, num sentido amplo, "tanto a referência à situação de uma norma no texto legal, como a referência à relação lógica ou teleológica de uma norma com outras normas, fins e princípios". Para ele, todavia, só se deve considerar sistemáticos em sentido estrito os argumentos que se referem a "relações lógicas entre normas". ${ }^{54} \mathrm{~A}$ análise do elemento teleológico possui, portanto, uma relevância especial para a compreensão do elemento sistemático.

\section{Os elementos teleológico e histórico}

A pergunta orientada pelo elemento teleológico ou finalístico direciona o intérprete para as finalidades normativas. Aqui, não se trata de estabelecer os fins do legislador do ponto de vista subjetivo, mas objetivo. Toma-se, nesse sentido, o legislador como um "sujeito hipotético", de maneira que as "afirmações finalistas dos intérpretes são hipóteses sobre os fins estabelecidos por este sujeito hipotético". Esse elemento faz com que o intérprete precise argumentar sobre as razões normativas, num processo de identificação dos bens jurídicos e estados de coisas que a norma visa tutelar e alcançar, e de determinação de suas implicações para o caso concreto: as consequências concretas; a representação concreta dos estados de coisas; e os meios de ação (condutas) necessários à promoção desses estados de coisas. ${ }^{55}$

Para a teoria da vontade objetiva do legislador, a lei é “desmembrada de suas origens" e a norma ganha uma autonomia relativa, de modo que a vontade

52 STF, Pleno. ADPF no 54. Rel. Min. Marco Aurélio, j. 12.4.2012, public. 24.4.2012.

53 ENGISCH, Karl. Introdução ao pensamento jurídico. Tradução de João Baptista Machado. 10. ed. Lisboa: Fundação Calouste Gulbenkian, 2008. p. 140 e ss.

54 ALEXY, Robert. Teoria da argumentação jurídica: a teoria do discurso racional como teoria da fundamentação jurídica. Tradução de Zilda H. Schild Silva. 3. ed. Rio de Janeiro: Forense, 2013. p. 237.

55 ALEXY, Robert. Conceito e validade do direito. Tradução de Gercélia Batista de O. Mendes. São Paulo: Martins Fontes, 2009. p. 143. 
do legislador histórico tem importância apenas subsidiária. ${ }^{56} \mathrm{~A}$ atuação criativa do intérprete voltada à resolução de um caso prático explica essa relativização. Guiado por um procedimento racional, o elemento teleológico é capaz de considerar tanto a constante e dinâmica mutação da sociedade como a atividade criativa exercida pelo intérprete frente a um caso prático, fatores que não podem ser ignorados na construção da norma jurídica concreta.

Por outro lado, o conceito de fimé bastante elástico e abrangente. Costuma-se considerar os fins de um ato humano tanto a partir das desejadas consequências fáticas mais específicas como por suas implicações mais abstratas. ${ }^{57} \mathrm{Na}$ verdade, é o intérprete quem vai distinguir o ato de suas consequências, numa atividade que envolve sua própria vontade (subjetiva) e seus preconceitos, isto é, o que ele experimentou como "atos" e/ou "consequências" durante a vida e a forma como ele os valoriza e os relaciona com o que interpreta concretamente, não havendo parâmetros "objetivos" para que se afirme algo como consequência de um ato. A norma, por sua vez, exige sempre que Ihe sejam atribuídas finalidades razoáveis, que se pretendem corretas, aptas a serem fundamentadas por um procedimento racional de argumentação.

Considerando esses aspectos, determinar as intenções reais do legislador se torna uma tarefa pretensa, principalmente quando o texto normativo foi elaborado há muito tempo. Mesmo na atividade legislativa contemporânea atuam jogos de poder político-econômico que, mais ou menos distantes do conhecimento público, tornam a pergunta pela vontade subjetiva do legislador uma tarefa sem respaldo concreto. 0 caráter especulativo dessa pergunta se aproximaria da teoria da vontade objetiva da lei (ou do legislador).

Essa pergunta também perde o sentido num contexto em que, numa burla à Constituição, o legislador programa a ineficácia social de normas jurídicas, considerando estrategicamente as deficiências estruturais da Administração Pública, que muitas vezes não possui condições fáticas ou corpo técnico suficiente para aplicar essas normas. Nesses casos, a promulgação das leis serve apenas como um produto político, de "eficácia simbólica", que legitimará a atuação política frente à sociedade e servirá como moeda de reeleição. ${ }^{58}$

Quando se considera o elemento teleológico, a dimensão objetiva dos direitos fundamentais adquire grande importância. As regras e os princípios de direitos fundamentais vinculam de maneira imediata também os poderes Legislativo e Executivo. Assim, frente à omissão do legislador e à inércia do administrador,

56 BONAVIDES, Paulo. Curso de direito constitucional. 30. ed. São Paulo: Malheiros, 2015. p. 464 e ss.

57 ENGISCH, Karl. Introdução ao pensamento jurídico. Tradução de João Baptista Machado. 10. ed. Lisboa: Fundação Calouste Gulbenkian, 2008. p. 142.

58 RAISER, Thomas. Grundlagen der Rechtssoziologie. 6. ed. Tübingen: Mohr Siebeck, 2013. p. 252 e ss. 
deve o Judiciário garantir aplicabilidade às normas constitucionais. Nesse sentido, não se fala em invasão ou usurpação de competências, uma vez que, na maioria desses casos, o Judiciário estará limitado a combater a inércia, determinando que os outros poderes ajam (se agirem), e não como eles devem agir.

Num sistema jurídico constitucionalizado como o brasileiro, o argumento teleológico é complementado pelo sistemático na medida em que o intérprete é levado a considerar de forma explícita a conexão tensionada entre os princípios de direitos fundamentais em jogo e os estados de coisas que eles visam promover, ainda que a norma em questão esteja localizada em nível ordinário. Essa complementação argumentativa densifica a estrutura normativa da decisão jurídica, limitando a subjetividade do intérprete através de um procedimento relativamente predeterminado que tornará mais previsível o caminho a ser percorrido até a decisão. Contudo, diferentemente dos demais elementos metódicos, o teleológico não guarda relação direta com o texto legal: quanto mais o intérprete se distancia do sentido literal, maior é a carga argumentativa assumida por ele. Assim, guiada pelo elemento teleológico sua argumentação carecerá de maior densificação linguístico-normativa.

Na argumentação teleológica, afirma-se um fim empiricamente constatável como algo objetivo. A passagem do plano prático-empírico (do caso concreto) para o objetivo-normativo e o seu retorno é o que exige a estrutura racional, e que assegura argumentativamente a racionalidade do procedimento, uma vez que quem escolhe e valora os fatos que integrarão definitivamente a norma e quem faz os juízos de prognose quanto às consequências de sua aplicação é o intérprete aplicador. Não obstante, impõe-se constantemente o dever de se observar a eventual pré-seleção de elementos materiais elaborada pelo legislador na hipótese ou no consequente normativos. ${ }^{59}$

A pergunta pelas finalidades normativas concede um considerável espaço argumentativo ao intérprete, que necessitará despender mais esforços para conseguir densificar racionalmente a fundamentação de suas escolhas. Assim, o elemento teleológico é capaz de resguardar e aumentar o nível de racionalidade da decisão, já que exige um convencimento argumentativo sobre aquilo que é o juridicamente correto. Por isso, o elemento teleológico é o que mais carece da complementação de outras formas de argumento, como a do elemento histórico, analisado a seguir.

O elemento histórico leva o intérprete a perguntar pelo contexto histórico em torno da elaboração do texto legal. Apesar de guardar relação com a interpretação

59 ALEXY, Robert. Teoria da argumentação jurídica: a teoria do discurso racional como teoria da fundamentação jurídica. Tradução de Zilda H. Schild Silva. 3. ed. Rio de Janeiro: Forense, 2013. p. 238 e ss. 
teleológica, não se trata de determinar os fins reais do legislador do ponto de vista histórico, ou a interpretação genética do texto legal, uma vez que, nos complexos processos legislativos atuais, não há mais “uma vontade" legislativa a ser descoberta; o que interessa é somente o texto aprovado e não as pretensas vontades subjacentes.

Trata-se, na verdade, de colher informações sobre a situação histórico-cultural da sociedade em que o texto foi elaborado para a melhor compreensão possível do significado da tradição frente ao caso concreto. ${ }^{60}$ Nesse sentido, o trabalho do intérprete "se assemelha ao do historiador", 61 pois ele é levado a considerar os precedentes legislativos da época de edição do texto legal, as propostas ou emendas de texto rejeitadas, bem como os fatos que foram documentados nesse contexto histórico. ${ }^{62}$

Uma das funções da atividade interpretativa é a de atualização do sentido da norma. Essa função é acentuada quando se leva em conta o elemento histórico. Alguns autores até afirmam que “a relevância do elemento histórico é inversamente proporcional ao tempo decorrido desde a edição da norma constitucional". ${ }^{63}$ Esse elemento atua subsidiariamente no estabelecimento das finalidades normativas de uma argumentação teleológica, tendo em vista que, a partir de argumentos sobre informações históricas, pode-se afirmar que o legislador estava condicionado ou limitado por sua tradição, e que essa limitação o impediu de considerar determinados fatos ou o condicionou a considerá-los com valores diferentes dos atuais. ${ }^{64}$

No mencionado caso de criminalização do aborto de fetos anencéfalos faria sentido perguntar se o estágio do conhecimento médico-científico na época da elaboração dos arts. 124, 126 e 128 do CP (1940) era capaz de diagnosticar a anencefalia e explicar suas nuances. Se não o fosse, fugiria à realidade do legislador incluir a anencefalia nas excludentes de ilicitude do art. 128. Apesar de não ser o único ponto de vista a determinar o sentido normativo, essas informações históricas têm sua importância para a compreensão do texto legal e para a construção de seu significado atual.

60 ENGISCH, Karl. Introdução ao pensamento jurídico. Tradução de João Baptista Machado. 10. ed. Lisboa: Fundação Calouste Gulbenkian, 2008. p. 144.

61 SOUZA NETO, Claudio Pereira de; SARMENTO, Daniel. Direito constitucional: teoria, história e métodos de trabalho. Belo Horizonte: Fórum, 2012. p. 413.

62 BARROSO, Luis Roberto. Interpretação e aplicação da Constituição: fundamentos de uma dogmática constitucional transformadora. 7. ed. São Paulo: Saraiva, 2014. p. 136.

63 SOUZA NETO, Claudio Pereira de; SARMENTO, Daniel. Direito constitucional: teoria, história e métodos de trabalho. Belo Horizonte: Fórum, 2012. p. 414.

64 ALEXY, Robert. Teoria da argumentação jurídica: a teoria do discurso racional como teoria da fundamentação jurídica. Tradução de Zilda H. Schild Silva. 3. ed. Rio de Janeiro: Forense, 2013. p. 234; 239; 240. 
O elemento histórico atua como um coadjuvante na interpretação normativa. Sempre que presente, ele necessita ser complementado por outros argumentos, tanto normativos quanto empíricos, para que a fundamentação da decisão seja minimamente racional e preencha as condições mais básicas do consenso. Assim, quanto mais densa for a argumentação de uma decisão mais chances ela terá de convencer a respeito de sua plausibilidade e de legitimar a atuação estatal.

Até agora, foi visto como os cânones se comportam no contexto do discurso prático-jurídico. Uma vez que se observe a evolução metódico-hermenêutica do pensamento jurídico racional, não cabe a exigência de abandonar os métodos clássicos. Por outro lado, a aplicação normativa sempre estará limitada pelas possibilidades práticas e individuais do caso concreto e de seus aplicadores, e caberá à dogmática jurídica oferecer soluções que observem essa limitação, ainda que tendentes a superá-las.

\section{Por uma metódica jurídica constitucionalmente correta}

A dimensão criativa do processo de aplicação normativa é incontornável; este fato exige uma atuação interpretativa minimamente racional. Guiada por uma pretensão de correção, essa atuação criativa do intérprete necessita ser racionalmente justificada, através da densificação argumentativa dos enunciados que sustentam as premissas normativas e que justificam a conclusão prática dessas premissas. Tanto as premissas quanto a sua conclusão estão ligadas a um caso concreto; por isso, elas precisam ser constantemente articuladas com as peculiaridades desse caso para que a passagem de uma premissa para a outra até a conclusão seja justificada através de enunciados que deverão ser "saturados" para que Ihes seja garantida densidade linguístico-normativa. Esse procedimento racional limita o arbítrio do intérprete-julgador, uma vez que suas escolhas interpretativas e o resultado prático da decisão precisam ser justificados com referência articulada ao caso concreto e ao sistema normativo.

Os cânones interpretativos auxiliam neste processo de saturação dos enunciados, representando diretivas que podem ser mais ou menos importantes para a densificação linguístico-normativa da argumentação jurídica referida a um caso concreto. Os cânones favorecem a conjugação necessária e articulada de argumentos normativos, jurisprudenciais, doutrinários e consequencialistas, formas essenciais de argumentos para qualquer decisão judicial estruturada por um discurso racional.

Após o início do processo brasileiro de abertura democrática, o ordenamento jurídico constitucionalizado passou a exigir maior abertura da interpretação 
normativa à sociedade. Isso significa a premente necessidade de inclusão da sociedade no processo de interpretação da Constituição, por um lado, e a justificação racionalizada das construções interpretativas, de outro. A concretização tanto da abertura interpretativa do direito quanto da justificação racional das decisões jurídicas é o primeiro passo para a efetiva legitimação democrática das instituições judiciárias brasileiras.

Os termos "textualismo" e "formalismo" são empregados na doutrina brasileira com conotação pejorativa, destacando-se a sua "condição patológica" que o sufixo "ismo" também engloba. ${ }^{65}$ No entanto, afigura-se mais produtivo considerá-los como expressões de práticas culturais ou de hábitos de pensamento, que representam menos uma patologia do que o congelamento de um momento da tradição melhor expresso pela luta por neutralidade e previsibilidade da aplicação normativa.

Essa luta ainda hoje representa a necessidade de aperfeiçoar as estruturas institucionais vigentes; foi esta que originou o textualismo e o formalismo e a mesma que agora orienta a sua reformulação. Isso não significa o abandono da lógica formal ou do respeito à literalidade do texto normativo, mas, sim, a redução do seu espaço de atuação e o reconhecimento da relatividade dos termos jurídicos e da subjetividade inerente a qualquer construção conceitual. Assim, abandonase a ilusão de neutralidade e de previsibilidade estritas, que passam a figurar como objetivos a serem seguidos através de um modelo de fundamentação das decisões jurídicas que privilegie a racionalidade e a previsibilidade dos argumentos que sustentam posições em determinadas condições concretas. Nesse contexto, a alteração das posições trabalha com diferentes cargas argumentativas, interrelacionadas com as condições concretas.

Há subáreas do direito (ex.: penal, tributário) em que, seja por tradição dogmática ou pela importância institucionalmente concedida aos bens jurídicos em jogo, seja por condições linguístico-normativas prevalentes de maior densidade mandamental, "o textualismo é mais forte, ou seja, em que a lei aparece como referência central para a argumentação". ${ }^{66}$ Mesmo nessas áreas, como visto no caso do tipo penal do aborto, há a possibilidade de termos legais geralmente determinados terem sua determinação reduzida ou suprimida em razão das condições concretas. Nesses casos, a literalidade do texto é respeitada na medida do racionalmente possível, mediante aumento da carga argumentativa imposta ao intérprete. Cabe, agora, um breve exame de como a racionalidade discursiva

65 Cf. FERREIRA, Aurélio Buarque de Holanda. Novo dicionário Aurélio da língua portuguesa. 3. ed. Curitiba: Positivo, 2004. p. 1135 e ss.

66 RODRIGUEZ, José Rodrigo. Como decidem as cortes? - Para uma crítica do direito (brasileiro). Rio de Janeiro: FGV, 2013. p. 75. 
é levada a cabo pela prática judicial brasileira, com o fim de justificar melhor a manutenção dos cânones interpretativos.

\section{0 modelo brasileiro de racionalidade judicial e a argumentação por autoridade}

O modelo brasileiro de racionalidade judicial é caracterizado pela predominância de argumentos de autoridade na fundamentação das decisões judiciais. ${ }^{67}$ A maior parte destes argumentos judiciais não é racional, não havendo uma articulação entre o conteúdo das estruturas argumentativas (conceitos normativos, ementas de decisões, passagens doutrinárias, fontes de direito internacional etc.) e o caso concreto objeto de julgamento. Assim, não é raro encontrar decisões em cuja fundamentação flutua apenas uma ementa de outro julgado como "motivo" ou "justificação" de sua conclusão, sem qualquer menção sobre a sua coerência, pertinência, relação ou simples ligação com o caso em questão. ${ }^{68}$ Nesses casos, não há a explicitação das razões de decidir, muito menos dos preconceitos do intérprete-julgador, de modo que seu controle intersubjetivo é inviabilizado e a decisão perde legitimidade.

A partir da análise de um número significativo de decisões judiciais, Rodriguez considera que, além de não haver articulação entre essas estruturas argumentativas e o caso concreto, é comum não haver qualquer coerência entre essas estruturas, que passam a figurar apenas como verdadeiros "golpes de autoridade". Mesmo nas decisões mais "completas" a argumentação por autoridade segue o mesmo modelo:

elabora-se uma tese, de saída, a partir de uma autoridade qualquer (legislação, doutrinador, caso julgado). Em seguida, são invocadas autoridades para corroborá-la, pouco importando a coerência entre elas, ou seja, a coerência entre as leis, casos julgados ou citações de doutrina utilizados. Por fim, é proposta uma solução para o caso como se ela fosse absolutamente óbvia, por ter sido, justamente,

67 RODRIGUEZ, José Rodrigo. Como decidem as cortes? - Para uma crítica do direito (brasileiro). Rio de Janeiro: FGV, 2013.

68 BARROSO, Luis Roberto; BARCELLOS, Ana Paula de. O começo da história: a nova interpretação constitucional e o papel dos princípios no direito brasileiro. In: SILVA, Virgílio Afonso da (Org.). Interpretação constitucional. São Paulo: Malheiros, 2010. p. 293-298. 
sustentada por praticamente "todos", todas as autoridades relevantes sobre o assunto. ${ }^{69}$

É bem verdade que esse modelo possui os mais diversos determinantes, além dos já mencionados (hábitos cotidianos dos operadores jurídicos, uma dogmática jurídica ainda em desenvolvimento, influências do pensamento positivista etc.), inclusive os que fogem às análises citadas. Todavia, a estrutura coletiva das decisões dos tribunais, que decidem numa votação por maioria, também é um determinante importante do modelo brasileiro de racionalidade judicial orientado por argumentação de autoridade.

A decisão colegiada não é uma conjugação da argumentação das decisões individuais, de maneira que a conclusão final resta muitas vezes sem referência aos argumentos dos votos vencidos, ou mesmo dos votos vencedores, que seriam bastante relevantes para se reconstruir o caminho percorrido até a conclusão da decisão. Além disso, o fato de as decisões se expressarem por ementas que trazem apenas enunciados como se fossem a fixação de regras é uma boa representação do primado da autoridade que se vale por si, não pela racionalidade de seus argumentos. Assim, a natureza predominantemente quantitativa das decisões colegiadas acaba por privilegiar ainda mais a argumentação por autoridade em detrimento da qualidade das decisões, que poderia ser melhorada com um modelo que privilegiasse a conjugação dos argumentos trazidos pelos votos individuais e se expressasse pela síntese desses argumentos, não por ementas como as elaboradas atualmente. ${ }^{70}$

Em outras palavras, a irracionalidade do modelo brasileiro se expressa pela inviabilidade de se reconstruir racionalmente os passos que precedem as decisões judiciais, tendo em vista que a argumentação por autoridade admite que se decida sem uma justificação individualizada, simplesmente com base na opinião do julgador, cuja fundamentação se limita a reafirmar a autoridade própria do juiz através de outras autoridades. Do ponto de vista hermenêutico, os preconceitos dos intérpretes-julgadores não são sequer explicitados, o que torna sua verificação impossível nos planos individual e intersubjetivo da compreensão. Nesse contexto, a participação da sociedade enquanto intérprete da Constituição, através das audiências públicas, pareceres técnicos etc., acaba servindo como mais um elemento para reafirmar a autoridade do julgador, uma vez que sua contribuição para a decisão não é explicitada, nem articulada com a conclusão.

69 RODRIGUEZ, José Rodrigo. Como decidem as cortes? - Para uma crítica do direito (brasileiro). Rio de Janeiro: FGV, 2013. p. 80 e ss.

70 RODRIGUEZ, José Rodrigo. Como decidem as cortes? - Para uma crítica do direito (brasileiro). Rio de Janeiro: FGV, 2013. p. 81 e ss. 
Frente à realidade brasileira, em que prevalece o modelo orientado pela argumentação de autoridade, os cânones interpretativos são essenciais para a racionalização do processo de aplicação normativa. Durante a construção de normas jurídicas enquanto elementos racionalizadores, eles induzem o intérpretejulgador a conjugar, de forma explícita, argumentos normativos (a partir dos conceitos legais), dogmáticos (jurisprudenciais e doutrinários), consequencialistas e de direito comparado, estabelecendo os limites parciais do texto literal (através de interpretações gramaticais) em razão do caso concreto e do sistema normativo constitucionalizado (com interpretações sistemáticas).

A partir desses limites o intérprete poderá assumir maiores ou menores cargas argumentativas para fixar tanto os estados de coisas (consequências fáticas sustentáveis por princípios) justificáveis frente ao caso concreto, através de argumentos sobre as finalidades normativas (com interpretações teleológicas), quanto os meios de ação (condutas sustentáveis por regras e princípios) necessários à consecução das consequências fáticas, que poderão ser mais ou menos sustentáveis pelos dados históricos documentados em torno da edição do texto legal (com interpretações históricas).

Nesse processo, os bens jurídicos contrapostos entram em colisão, que deve ser solucionada pelo intérprete-julgador através da ponderação de bens e valores. Ocorre, entretanto, que no contexto brasileiro a ponderação prévia tem tomado o lugar da ponderação em concreto, situação que contribui para o modelo brasileiro de racionalidade deficiente. Diante dessa situação, mostra-se especialmente relevante a análise da ponderação prévia.

\section{0 problema da ponderação prévia}

No contexto brasileiro de racionalidade deficiente, o método da ponderação de interesses, responsável pela resolução de conflitos normativos, tem sido invocado sem qualquer articulação com o caso concreto, e muitas vezes acaba figurando apenas como mais um "golpe de autoridade" teórica. Isso significa que muitas vezes o intérprete-julgador diz estar realizando uma ponderação quando na verdade ele está apenas citando os bens jurídicos abstratos e fazendo uma escolha entre eles, sem qualquer consideração sobre o que esses bens representam no caso concreto. Nesses casos, afirma-se que a ponderação se dá previamente, ou ex ante. ${ }^{71}$

71 ALEXY, Robert. Teoria dos direitos fundamentais. Tradução de Virgílio Afonso da Silva. 2. ed. São Paulo: Malheiros, 20144, p. 600. 
A ponderação, ou sopesamento, exige que o intérprete-julgador atribua pesos (leve, moderado ou forte) à restrição de um bem (interesse, valor), que representam o grau de afetação ou de intervenção concreta sofrida por esse bem em razão da sua colisão com outro. Essa afetação concreta precisa ser justificada pela importância da satisfação do outro bem. Quanto maior for o grau de intervenção em um bem, maior deverá ser a importância da satisfação do bem oposto. Como na maior parte das vezes os bens jurídicos colidentes têm pesos abstratos (ou prima-facie) iguais, frequentemente "tudo dependerá exclusivamente dos pesos concretos". ${ }^{72}$

Ocorre que no contexto brasileiro a ponderação não é levada a cabo tal como o proposto teoricamente. Nesse contexto, não há razões para cunhar de “irracional” o método da ponderação em si simplesmente a partir do seu mau exercício pela prática brasileira. Por outro lado, Alexy demonstra que a ponderação, como forma de argumento do discurso jurídico-racional, não é irracional, uma vez que a "racionalidade de um esquema inferencial depende essencialmente da questão se ele combina premissas que, enquanto tais, podem por sua vez ser fundamentadas". ${ }^{73}$

Dentro do contexto do discurso jurídico racional, em que as posições são guiadas por argumentos, a possibilidade de se chegar a soluções contraditórias através da ponderação por si só não a torna irracional, uma vez que a sua racionalidade dependerá de como o intérprete irá saturar os enunciados que pretendem fundamentar a conclusão do sopesamento. A verdadeira irracionalidade está no modelo cultural brasileiro de aplicação normativa orientado por argumentos de autoridade. Frente a esse modelo ganham importância e força os movimentos que trabalham pela racionalização do processo de aplicação de normas e pela abertura da interpretação normativa à sociedade como etapa desse processo.

É esse o caminho trilhado por aqueles que defendem a presença dos cânones interpretativos no processo de aplicação normativa. Além do mais, impõe-se a necessidade de reconhecer o papel dos cânones no processo de abertura do direito à sociedade, iniciada pelos tribunais superiores brasileiros, que passaram a se valer especialmente do amicus curiae (além das audiências públicas, dos pareceres técnicos, etc.), como forma de conceder mais legitimidade às construções normativo-interpretativas de suas decisões. Neste sentido houve no Brasil, sem dúvida, o processo de abertura da interpretação constitucional à sociedade.

72 ALEXY, Robert. Teoria dos direitos fundamentais. Tradução de Virgílio Afonso da Silva. 2. ed. São Paulo: Malheiros, 2014 p. 601.

73 ALEXY, Robert. Teoria dos direitos fundamentais. Tradução de Virgílio Afonso da Silva. 2. ed. São Paulo: Malheiros, 2014 p. 158. 
Face ao contexto brasileiro, nos âmbitos legislativo, jurisprudencial e doutrinário, convencem menos as afirmações no sentido de que qualquer forma do método jurídico deve ser abandonada. Enquanto a ponderação de interesses já conquistou seu lugar na legislação brasileira, os cânones interpretativos têm espaço garantido no processo de aplicação normativa da jurisprudência pátria. Mais difícil do que simplesmente propor o abandono aos métodos é trabalhar por sua reconstrução e aperfeiçoamento. Com o auxílio do legislador e com o amadurecimento da dogmática jurídica, será possível seguir com o processo de abertura procedimental da interpretação normativa no Brasil. Ao lado da ponderação de interesses, a institucionalização dos cânones interpretativos enquanto diretivas interpretativas representaria um grande passo nesse processo.

Por outro lado, impõe-se a necessidade de se reconhecer a importância da argumentação racional para o agir jurídico-metódico. Processos como a ponderação e os cânones interpretativos poderiam ser considerados arbitrários se não fossem postos como referência dentro de uma argumentação jurídica. ${ }^{74}$ Por isso, cumpre fazer uma breve análise do papel dos cânones interpretativos para um processo metódico de construção de normas.

\section{Os cânones interpretativos no processo de construção de normas}

A partir de uma conceituação específica das espécies normativas, pode-se analisar de maneira breve o papel dos cânones interpretativos frente à construção de normas no processo de aplicação normativa. Como visto, a importância de cada cânone só pode ser determinada na medida em que este contribui para a resolução do caso concreto. Para a construção de regras e de princípios, entretanto, alguns dos cânones podem assumir funções mais ou menos distintas, a depender do conceito de normas de que parta o intérprete-aplicador.

Como vimos, o processo de aplicação normativa está sempre em construção, condicionado às limitações individuais do intérprete, ao modo com que ele conjuga discursivamente o sistema normativo e os fatores que se apresentam em cada caso concreto à maior ou menor determinação dos termos jurídicos trazidos no texto normativo. Esse processo é muitas vezes determinado por fatores contingentes, que escapam a qualquer análise prévia.

74 TRIVISONNO, Alexandre T. Gomes. Estudo introdutório: a teoria discursiva do direito de Alexy e as duas questões fundamentais da filosofia do direito. In: ALEXY, Robert. Teoria discursiva do direito. 2. ed. Rio de Janeiro: Forense Universitária, 2015. p. 27. 
O processo de justificação de decisões possui etapas que vão desde a construção das premissas normativas e fáticas até a justificação argumentativa da sua passagem para a conclusão normativa. ${ }^{75}$ Nesse contexto, os cânones guiam a estrutura interpretativa da construção das premissas e da justificação da passagem para a conclusão. A depender da natureza das normas e das peculiaridades do caso concreto, cada cânone pode assumir uma função mais ou menos extensiva em cada etapa da construção e justificação dessas premissas.

Em relação às regras, o elemento literal poderá assumir uma função mais extensiva na construção conceitual das premissas normativas e fáticas, mormente na resolução dos conflitos normativos. Isso porque no caso das regras normalmente "há maior determinação do comportamento em razão do caráter descritivo ou definitório do enunciado prescritivo", de modo que a identificação da presença de um comportamento obrigatório, permitido ou proibido muitas vezes dependerá apenas das habilidades linguísticas ordinárias do intérprete enquanto falante de uma língua específica, que normalmente serão suficientes para que ele identifique o comportamento descrito no enunciado prescritivo de uma regra.

Pode acontecer, contudo, que um termo jurídico indeterminado integre o texto normativo de uma regra. Nesses casos, abre-se um espaço para que o intérprete construa o sentido do termo através de uma ponderação de bens e interesses, fazendo referência ao caso concreto, ao sistema normativo, às finalidades normativas e aos princípios colidentes, com o auxílio dos elementos sistemático e teleológico de interpretação. É necessário “ponderar a razão geradora da regra com as razões substanciais para o seu não cumprimento, diante de determinadas circunstâncias, com base na finalidade da própria regra ou em outros princípios". ${ }^{76}$ Dada a ausência de um sentido literal a ser considerado, o elemento gramatical de interpretação costuma ter seu espaço de atuação reduzido ou suprimido.

Pelo fato de as regras serem “primariamente retrospectivas", isto é, por elas descreverem situações de fato já efetivamente experimentadas, com relação às quais já há uma "experiência acumulada no passado", a construção conceitual dos fatos elaborada pelo intérprete poderá contar de forma mais intensiva com dados históricos documentados, além de dados técnico-empíricos, analogias etc. Entretanto, isso não significa que a construção de princípios prescinda da

75 ATIENZA, Manuel. As razões do direito: teoria da argumentação jurídica. Tradução de Maria Cristina G. Cupertino. 2. ed. Rio de Janeiro: Forense Universitária, 2014. p. 33.

76 ÁVILA, Humberto. Teoria dos princípios: da definição à aplicação dos princípios jurídicos. 15. ed. São Paulo: Malheiros, 2014. p. 98. 
consideração de situações de fato já experimentadas, mas que no caso das regras a atividade do intérprete nesse sentido será mais intensa. ${ }^{77}$

Por outro lado, a justificação da correspondência entre a construção conceitual da descrição normativa e a construção conceitual dos fatos poderá ser guiada em maior escala pelos elementos sistemático e teleológico de interpretação. Como a avaliação dessa correspondência deverá ser orientada pela finalidade normativa e pelos princípios axiologicamente sobrejacentes à regra, nessa etapa haverá maior espaço para a atuação argumentativa do intérprete, que deverá determinar o significado do sistema jurídico e de suas finalidades, estabelecendo a correlação axiológica e finalística entre as construções conceituais em questão, através do elemento sistemático e, principalmente, do elemento teleológico. Consequentemente, é nessa etapa da aplicação das regras em que haverá um aumento da carga argumentativa do intérprete para que suas escolhas, a respeito da finalidade normativa e dos princípios incidentes que orientarão a justificação da correspondência, restem saturadas.

Já com relação aos princípios, o elemento teleológico é fundamental para garantir a racionalidade do processo de sua construção e aplicação. Uma vez que para os princípios “o elemento descritivo cede lugar ao elemento finalístico", por eles estabelecerem "um estado de coisas para cuja realização é necessária a adoção de determinados comportamentos", ${ }^{78}$ grande parte da atuação do intérprete no momento da construção dos princípios será guiada pelo elemento teleológico.

Assim, o esforço argumentativo do intérprete-aplicador se voltará para a justificação das qualidades que ele identifica no estado de coisas ideal comandado pelo princípio, e, de forma secundária, para a justificação tanto dos comportamentos necessários à consecução desse estado ideal como dos possíveis efeitos da adoção desses comportamentos. Essa atividade demandará uma intensa argumentação com a conjugação de diversas formas de argumento, inclusive de argumentos a respeito do sentido literal dos termos presentes no texto normativo, de sua constituição histórica documentada e de seu significado para o sistema jurídico.

O fato de os princípios serem normas “primariamente prospectivas" demanda do intérprete um juízo de prognose que estabelecerá uma correlação entre os efeitos dos comportamentos tidos como necessários à consecução do estado de coisas e as qualidades que ele identificou no estado de coisas. Interpretações

77 ÁVILA, Humberto. Teoria dos princípios: da definição à aplicação dos princípios jurídicos. 15. ed. São Paulo: Malheiros, 2014. p. 100.

78 ÁVILA, Humberto. Teoria dos princípios: da definição à aplicação dos princípios jurídicos. 15. ed. São Paulo: Malheiros, 2014. p. 95. 
históricas podem ser particularmente importantes para esse juízo de prognose enquanto figurarem como bases comparativas para a interpretação voltada para o futuro. Nessa etapa, a carga argumentativa é mais elevada do que nas outras, vez que os parâmetros normativos e fáticos diretos são, em geral, mais escassos.

Com esse exame sucinto da interação entre os cânones interpretativos e o processo de construção normativa, percebe-se que eles estão presentes em quase todas as etapas da aplicação normativa, seja na aplicação de regras seja na de princípios. Seria difícil imaginá-las sem sua interação com os cânones, independentemente do nome que se dá aos elementos literal, histórico, sistemático e teleológico. Quanto mais os cânones interpretativos forem levados a sério pela dogmática jurídica, mais chances eles terão de contribuir para o desenvolvimento do discurso jurídico-racional no contexto brasileiro.

\section{Conclusão}

Após a virada linguístico-pragmática da filosofia e da hermenêutica contemporâneas, não há mais espaço para o emprego de métodos com pretensões de universalidade e de objetividade nas ciências humanas, inclusive na ciência jurídica. Não há mais como negar a importância do contexto pragmático para a formação e estruturação dos sentidos dentro do processo de construção e aplicação das normas jurídicas. Assim, os procedimentos metódicos vêm orientar a atuação do intérprete aplicador no “âmbito de sua relatividade”. Isso significa que são as peculiaridades do caso concreto e a atuação argumentativa do intérprete que indicarão os melhores caminhos para sua resolução, sempre sobre o pano de fundo do discurso prático-jurídico.

Para que a compreensão tenha a menor quantidade de vícios quanto possível, os preconceitos individuais necessitam ser intersubjetivamente controlados. A necessidade de controle dos preconceitos, da dimensão criativa e individual da compreensão, se agrava dentro do agir científico-jurídico, tendo em vista a necessidade de se chegar a uma decisão que se pretende correta, defensável, cujos efeitos valerão para toda uma coletividade. É do processo de compreensão que envolve o agir jurídico que se ocupa a hermenêutica jurídica.

Inegável é a contribuição da hermenêutica filosófica para a virada linguística da filosofia contemporânea. Para a ciência jurídica, essa contribuição restou mais limitada, principalmente em razão das peculiaridades em torno do processo de aplicação normativa, de estrutura discursiva predominantemente monológica. Essa estrutura realça a necessidade de se considerar cada vez mais o plano intersubjetivo da compreensão humana e pelo caráter circunstancial da construção 
normativa. Resta à dogmática jurídica a tarefa de desenvolver melhor o sentido da virada linguístico-pragmática da hermenêutica e da filosofia para a realidade brasileira.

Para o direito, o método tem função racional, expositiva e organizativa, instrumental às pretensões de fundamentabilidade, de correção, de decidibilidade e de obrigatoriedade, inerentes à aplicação normativa. O fato de muitas vezes o emprego desses métodos gerar interpretações arbitrárias costuma ter causas mais variadas do que uma relação de sua aplicação com a herança da filosofia da consciência. A origem dessas distorções normalmente reside menos nessa herança do que na má-compreensão da função dos métodos invocados, encoberta pelo modelo brasileiro de fundamentação deficiente das decisões jurídicas.

Uma vez que se observe a evolução metódico-hermenêutica do pensamento jurídico racional, não cabem afirmações como a de que os métodos clássicos devem ser abandonados. Por outro lado, a aplicação normativa sempre estará limitada pelas possibilidades práticas e individuais do caso concreto e de seus aplicadores, e caberá à dogmática jurídica oferecer soluções que observem essa limitação, ainda que tendentes a superá-las.

Não obstante a falta de preocupação nas graduações e na doutrina brasileira mais tradicional com o ensino e aperfeiçoamento dos meios metódicos interpretativos, a jurisprudência já os vem empregando explícita ou implicitamente há bastante tempo em suas decisões. Contudo, o contexto brasileiro de racionalidade deficiente, dominado pela argumentação de autoridade, acaba por desvirtuar as verdadeiras funções dos métodos interpretativos, que servem apenas como mais um argumento de autoridade. Após o início do processo de abertura democrática, essa realidade prática não pode ser ignorada por uma dogmática jurídica que se pretenda constitucionalmente correta, adequada.

Por outro lado, o sistema brasileiro vem ganhando com as inovações legislativas que reconheceram a necessidade de atualização face à nova realidade democrática, pautada pela luta pela abertura interpretativa do processo de aplicação normativa e pela justificação das decisões jurídicas. Além disso, com sua elevação em nível normativo, a ponderação de interesses ganhou importância institucional e teve seu emprego condicionado a uma argumentação racional que considere e torne explícito o papel das peculiaridades do caso concreto para o sopesamento.

Nesse contexto de racionalização do sistema jurídico, abandonar os métodos interpretativos significaria regredir, uma vez que eles são responsáveis por estruturar racionalmente o processo de exposição das razões, dos argumentos que fundamentam as decisões, além de tornarem explícita a medida em que as 
diversas participações interpretativas da sociedade influenciaram a conclusão final dessas decisões.

Os cânones interpretativos têm seu espaço de respeito dentro de qualquer construção normativa e merecem ser elevados em nível normativo através de sua institucionalização legislativa. A par da ponderação de bens, e dentro de um contexto em processo de racionalização, como o brasileiro, a institucionalização dos quatro cânones contribuiria enormemente para o aperfeiçoamento do modelo brasileiro de racionalidade jurídica, com o constante auxílio da dogmática jurídica.

\title{
Legal hermeneutics and deficient use of methods in the context of law application in Brazil
}

\begin{abstract}
The paper aims to analyze the coherence of the critics towards the interpretation canons in contemporary Brazilian law. While the nacional doctrine does not give them space any more, the judicial practice often employs them without proper care, especially as a resource of authority. In this context, the extinction of any form of juridical method might represent a restriction of the normative interpretation process and diminish the legitimacy of judicial decisions, which suffer from the low level of argumentative justification. Guided within a juridical-rational speech based on the claims of correctness, communicability and representation, the interpretation canons still have important structural and expository functions which are indispensable to the rationality of interpretation and application of legal norms.
\end{abstract}

Keywords: Canons of interpretation. Hermeneutics. Discourse theory of law.

Summary: 1 Introduction - 2 Legal hermeneutics in Brazilian traditional doctrine: disregard for interpretation methods - $\mathbf{3}$ Most common criticism against interpretation canons - $\mathbf{4}$ Interpretation canons and discursive rationality - $\mathbf{5}$ Literal and systematic elements $\mathbf{- 6}$ Teleological and historical elements - $\mathbf{7}$ For a constitutionally correct use of legal methods $\mathbf{- 8}$ The Brazilian model of judicial rationality and appeal to authority - $\mathbf{9}$ The problem of previous balancing - $\mathbf{1 0}$ Interpretation canons in the process of normative construction - $\mathbf{1 1}$ Conclusion - References

\section{Referências}

ALEXY, Robert. Conceito e validade do direito. Tradução de Gercélia Batista de O. Mendes. São Paulo: Martins Fontes, 2009.

ALEXY, Robert. Teoria da argumentação jurídica: a teoria do discurso racional como teoria da fundamentação jurídica. Tradução de Zilda H. Schild Silva. 3. ed. Rio de Janeiro: Forense, 2013.

ALEXY, Robert. Teoria discursiva do direito. Tradução de Alexandre Travessoni Gomes Trivisonno. 2. ed. Rio de Janeiro: Forense Universitária, 2015.

ALEXY, Robert. Teoria dos direitos fundamentais. Tradução de Virgílio Afonso da Silva. 2. ed. São Paulo: Malheiros, 2014. 
ATIENZA, Manuel. As razões do direito: teoria da argumentação jurídica. Tradução de Maria Cristina G. Cupertino. 2. ed. Rio de Janeiro: Forense Universitária, 2014.

ÁVILA, Humberto. Teoria dos princípios: da definição à aplicação dos princípios jurídicos. 15. ed. São Paulo: Malheiros, 2014.

BARROSO, Luis Roberto. Interpretação e aplicação da Constituição: fundamentos de uma dogmática constitucional transformadora. 7. ed. São Paulo: Saraiva, 2014.

BARROSO, Luis Roberto; BARCELLOS, Ana Paula de. O começo da história: a nova interpretação constitucional e o papel dos princípios no direito brasileiro. In: SILVA, Virǵlio Afonso da (Org.). Interpretação constitucional. São Paulo: Malheiros, 2010.

BONAVIDES, Paulo. Curso de direito constitucional. 30. ed. São Paulo: Malheiros, 2015.

CUNHA JÚNIOR, Dirley da. Curso de direito constitucional. 5. ed. Salvador: JusPodivm, 2011.

DIDIER JÚNIOR, Fredie; CUNHA, Leonardo José C. da. Curso de direito processual civil: meios de impugnação às decisões judiciais e processo nos tribunais. 10. ed. Salvador: JusPodivm, 2012.

ENGISCH, Karl. Introdução ao pensamento jurídico. Tradução de João Baptista Machado. 10. ed. Lisboa: Fundação Calouste Gulbenkian, 2008.

FERREIRA, Aurélio Buarque de Holanda. Novo dicionário Aurélio da língua portuguesa. 3. ed. Curitiba: Positivo, 2004.

GADAMER, Hans-Georg. Verdade e método l: traços fundamentais de uma hermenêutica filosófica. Tradução de Flávio P. Meurer. 14. ed. Petrópolis: Vozes, 2014.

HÄBERLE, Peter. Hermenêutica constitucional. A sociedade aberta dos intérpretes da constituição: contribuição para a interpretação pluralista e "procedimental" da constituição. Tradução de Gilmar F. Mendes. Porto Alegre: Sergio Fabris, 2002.

HABERMAS, Jürgen. Verdade e justificação: ensaios filosóficos. Tradução de Milton C. Mota. São Paulo: Loyola, 2004.

HEIDEGGER, Martin. Ser e tempo. Tradução de Fausto Castilho. Edição bilíngue. Campinas: Unicamp; Petrópolis: Vozes, 2012.

KELSEN, Hans. Teoria pura do direito. Tradução de João Baptista Machado. 8. ed. São Paulo: Martins Fontes, 2009.

KRELL, Andreas J. Discricionariedade administrativa e conceitos legais indeterminados: limites do controle judicial no âmbito dos interesses difusos. 2. ed. Porto Alegre: Livraria do Advogado, 2013.

KRELL, Andreas J. Entre desdém teórico e aprovação na prática: os métodos clássicos de interpretação jurídica. Revista de Direito GV, São Paulo, v. 10, p. 295-320, jan./jun. 2014.

MAXIMILIANO, Carlos. Hermenêutica e aplicação do direito. 19. ed. Rio de Janeiro: Forense, 2003.

MENDES, Gilmar Ferreira; BRANCO, Paulo Gustavo Gonet. Curso de direito constitucional. 8. ed. São Paulo: Saraiva, 2013. 
MENDES, Gilmar Ferreira; VALE, André Rufino do. O pensamento de Peter Häberle na jurisprudência do STF. Observatório da Jurisdição Constitucional, Brasília, ano 2, 2008/2009.

MORAES, Alexandre de. Direito constitucional. 27. ed. São Paulo: Atlas, 2011.

MÜLLER, Friedrich. Teoria estruturante do direito. Tradução de Peter Naumann e Eurides A. de Souza. 3. ed. São Paulo: RT, 2011.

OLIVEIRA, Manfredo Araújo de. Reviravolta linguístico-pragmática na filosofia contemporânea. 4. ed. São Paulo: Loyola, 2015.

PEIXINHO, Manoel Messias. A interpretação da Constituição e dos princípios fundamentais: elementos para uma hermenêutica constitucional renovada. 3. ed. Rio de Janeiro: Lumen Juris, 2003.

RAISER, Thomas. Grundlagen der Rechtssoziologie. 6. ed. Tübingen: Mohr Siebeck, 2013.

RODRIGUEZ, José Rodrigo. Como decidem as cortes? - Para uma crítica do direito (brasileiro). Rio de Janeiro: FGV, 2013.

SILVA, José Afonso da. Curso de direito constitucional positivo. 35. ed. São Paulo: Malheiros, 2012.

SOUZA NETO, Claudio Pereira de; SARMENTO, Daniel. Direito constitucional: teoria, história e métodos de trabalho. Belo Horizonte: Fórum, 2012.

STRECK, Lenio L. A interpretação do direito e o dilema acerca de como evitar juristocracias: a importância de Peter Häberle para a superação dos atributos (Eigenschaften) solipsistas do direito. Observatório da Jurisdição Constitucional, Brasília, ano 4, 2010/2011.

STRECK, Lenio L. Hermenêutica jurídica $e(m)$ crise: uma exploração hermenêutica da construção do direito. 4. ed. Porto Alegre: Livraria do Advogado, 2003.

STRECK, Lenio L. Verdade e consenso: Constituição, hermenêutica e teorias discursivas. 5. ed. São Paulo: Saraiva, 2014.

TRIVISONNO, Alexandre T. Gomes. Estudo introdutório: a teoria discursiva do direito de Alexy e as duas questões fundamentais da filosofia do direito. In: ALEXY, Robert. Teoria discursiva do direito. 2. ed. Rio de Janeiro: Forense Universitária, 2015.

Informação bibliográfica deste texto, conforme a NBR 6023:2002 da Associação Brasileira de Normas Técnicas (ABNT):

KRELL, Andreas J.; PAIVA, Raíi Moraes Sampaio de. Hermenêutica jurídica e uso deficiente de métodos no contexto da aplicação do direito no Brasil. Direitos Fundamentais \& Justiça, Belo Horizonte, ano 11, n. 37, p. 185-218, jul./dez. 2017.

Recebido em: 22.02.2017

Pareceres: 22.05.2017 e 23.06.2017

Aprovado em: 17.10.2017 